\title{
of Semidesert Grasses to Seasonal Rest
}

\section{S. CLARK MARTIN}

Highlight: Perennial grasses on semidesert range in southern Arizona increased more in 8 years under spring-summer (March-October) rest 2 years out of 3 than under continuous yearlong grazing or any of 13 other rest schedules. A three-pasture grazing system that provides spring-summer rest 2 years in 3 is being tested on the Santa Rita Experimental Range.

Most semidesert grassland and grassshrub ranges in the southwest are grazed yearlong. Many, if not most, of these ranges produce less forage than they could. Continuous yearlong grazing, even at moderate intensity, creates zones of heavy use around water. But systems of rotation and deferment have not always been successful either. Too often, the start toward recovery during a rest period is nullified by the effects of accelerated forage removal when the range is again grazed. The question is-when, how long, and how often should a range be rested?

Several schedules of grazing and rest were evaluated on semidesert grass-shrub cattle range. The study was conducted from July 1, 1962, to October 31, 1969, on the Santa Rita Experimental Range near Tucson, Ariz. Rest, as used in this paper, is protection from cattle grazing.

From the standpoint of plant growth, a year in southern Arizona consists of three rather distinct 4-month periods: summer, winter, and spring. Summer (July-October) includes the summer rainy season and the relatively dry early fall. Warm-season perennial grasses make almost all of their annual growth, mature, and set seed during this period. Winter (November-February) is the dormant period for warm-season perennial grasses.

The author is principal range scientist, Rocky Mountain Forest and Range Experiment Station, Forest Service, U. S. Department of Agriculture. Research reported here was conducted at Tucson, in cooperation with University of Arizona. Station's central headquarters is maintained at Fort Collins, in cooperation with Colorado State University.

Manuscript received September 15, 1972.
Above-average winter precipitation may wet the soil to a depth of $2 \mathrm{ft}$ or more; the rate of evaporation is low enough that moisture from successive storms accumulates in the soil. Winter annuals germinate during this period but make little top growth until temperatures rise late in February or in March. Spring (MarchJune) begins with a period of early growth initiated largely on accumulated winter moisture. Spring rains, if any, usually end by mid-April. Herbaceous plants are dormant due to drought from mid-May through June.

\section{Study Methods}

The experiment included 15 restgrazing schedules applied to plots $20 \mathrm{ft}$ square (Table 1). Schedules were assigned at random and were replicated three times in each of three 45-plot blocks. Grazing was excluded during rest periods by movable wire exclosures. Replications of the schedules were started on successive years to even out possible climatic effects.

Influences other than cattle grazing were eliminated insofar as possible. Shrubs were removed or killed so they would not compete with grasses for moisture or nutrients or interfere mechanically with grazing on the study plots. Velvet mesquites (Prosopis juliflora var. velutina) were killed with diesel oil. Burroweeds (Aplopappus tenuisectus) between plots on the study area were grubbed; those on study plots were pulled by hand. Cactus and other shrubs that would interfere with grazing were removed with as little disturbance as possible. Rodents and ants were poisoned as needed.

Plots were not placed on areas subject to runoff or on cattle trails. Short drift fences were erected to divert the cattle when new trails began to develop across plots.

The basic data consisted of (1) density (plants per $\mathrm{ft}^{2}$ ) by species of perennial grasses and perennial forbs, (2) herbage production (1b/acre) of annual and perennial grasses, and (3) ocular estimates of utilization (percentage of herbage removed) on perennial grasses. Densities by species were recorded each year on the same 2 by $10 \mathrm{ft}$ sample area within each 20 by $20 \mathrm{ft}$ treatment plot. Herbage production and utilization were estimated each year on the same 1 by $9.6 \mathrm{ft}(9.6$ $\mathrm{ft}^{2}$ ) sample area within each treatment plot. The relation between estimated and actual herbage yields on temporary plots $9.6 \mathrm{ft}^{2}$ was used to adjust ocular estimates on the permanent samples. Density and utilization were measured around July 1 each year; herbage production was recorded around November 1.

The most common perennial forbs were leatherweed croton (Croton corym-

Table 1. Seasons and frequencies of rest evaluated in study.

\begin{tabular}{lcccc}
\hline \hline & \multicolumn{4}{c}{ Rest frequency } \\
\cline { 2 - 5 } \multicolumn{1}{c}{ Season rested } & 1 year in 3 & 2 years in 3 & 3 years in 4 & Every year \\
\hline Summer (July-October) & $\mathrm{x}$ & $\mathrm{x}$ & $\mathrm{x}$ & \\
Winter (November-February) & $\mathrm{x}$ & $\mathrm{x}$ & $\mathrm{x}$ & $\mathrm{x}$ \\
Spring (March-June) & $\mathrm{x}$ & $\mathrm{x}$ & $\mathrm{x}$ & \\
Spring-summer (March-October) & $\mathrm{x}$ & $\mathrm{x}$ & & \\
Yearlong (July-June) & $\mathrm{x}$ & $\mathrm{x}$ & $\mathrm{x}$ \\
None & & & & \\
\hline
\end{tabular}


Table 2. Seasonal rainfall (inches) and yields (lb/acre, air dry) of annual and perennial grass herbage.

\begin{tabular}{llrlccc}
\hline \hline & \multicolumn{2}{c}{ Rainfall } & & \multicolumn{3}{c}{ Herbage production } \\
\cline { 2 - 3 } \cline { 5 - 7 } Year & $\begin{array}{l}\text { Nov.- } \\
\text { Jan. }\end{array}$ & $\begin{array}{c}\text { June- } \\
\text { Sept. }\end{array}$ & & $\begin{array}{c}\text { Annual } \\
\text { grasses }\end{array}$ & $\begin{array}{c}\text { Perennial } \\
\text { grasses }\end{array}$ & Total \\
\hline 1962 & 4.62 & 4.65 & & 22 & 27 & 49 \\
1963 & 2.75 & 7.69 & & 488 & 21 & 509 \\
1964 & 3.58 & 11.45 & & 138 & 43 & 181 \\
1965 & 1.98 & 4.80 & & 32 & 57 & 89 \\
1966 & 7.63 & 9.52 & & 141 & 82 & 223 \\
1967 & .76 & 9.53 & & 224 & 171 & 395 \\
1968 & 6.13 & 5.30 & & 32 & 99 & 131 \\
1969 & 2.27 & 10.71 & & 156 & 72 & 228 \\
Average & 3.72 & 7.96 & & 154 & 72 & 226 \\
\hline
\end{tabular}

bulosus) and evolvulus (Evolvulus arizonicus). Common perennial grasses were Santa Rita threeawn (Aristida glabrata), tall threeawns ( $A$. hamulosa and $A$. ternipes), and Rothrock grama (Bouteloua rothrockii). Species groupings used in the analysis were perennial grasses other than Rothrock grama, total perennial grasses, and total forbs. Rothrock grama was treated separately because it is short-lived and changes more from year to year than other perennial grasses do.

Data for all years were combined in analyses of variance. Means for the last two measurements (1968 and 1969) were also subjected to analysis of covariance, using means for the first two measurements (1962 and 1963) as the covariant. Relative rates of change were evaluatcd by regression.

\section{Results}

Rainfall and herbage production varied greatly from year to year (Table 2). Herbage yields of perennial grasses were more closely associated with the sum of current and past summer rainfall than with rainfall during any of several other periods, but none of the rainfall-herbage production regressions were significant at the 95\% level. Herbage yields of annual grasses, however, were negatively related $(r=-0.78)$ to rainfall during the preceding June-January.

\section{Changes in Density}

and Herbage Production

Average yields of grasses did not change significantly with time during the study period. Annual grasses decreased slightly under all grazing schedules $(r=$ -0.08 to -0.30 ), but perennial grasses increased quite strongly $(r=0.39$ to 0.84 ). Perennial grass production (average for all treatments) was over three times as great at the end of the study (1968-69 average) as at the start (1962-63 average).

The average density of perennial grasses increased from 0.2 plant per $\mathrm{ft}^{2}$ during the first 2 years of the study to grazing.
1.0 in the final 2 years. Densities of most perennial grasses changed from year to year regardless of grazing treatment.

Adjusted means from the analysis of covariance showed that total perennial grass herbage production (1968-69 average) was greatest on plots that had been rested March-October 2 years out of 3 (Table 3 ). The effects of grazing schedules on total perennial grass density were less clear cut. Although spring-summer rest 2 years out of 3 did result in the highest total perennial grass density, spring rest 1 year in 3 , spring-summer rest 1 year in 3 , yearlong rest 1 or 2 years in 3 , and summer rest 3 years in 4 resulted in densities that were not significantly lower. If data for Rothrock grama are removed from the perennial grass totals, spring-summer rest 2 years out of 3 showed significantly higher density values than any other treatment except yearlong rest 2 years out of 3 .

The response of perennial grasses to rest is evident in density changes with time. Densities of perennial grasses other than Rothrock grama increased under all treatments (Fig. 1). Density increases under 4-month rest periods generally were little if any greater than under yearlong grazing, however. For example, perennial grass density on plots rested in the same season 1 or 2 years out of 3 increased no more than under yearlong grazing regardless of season. Rest 3

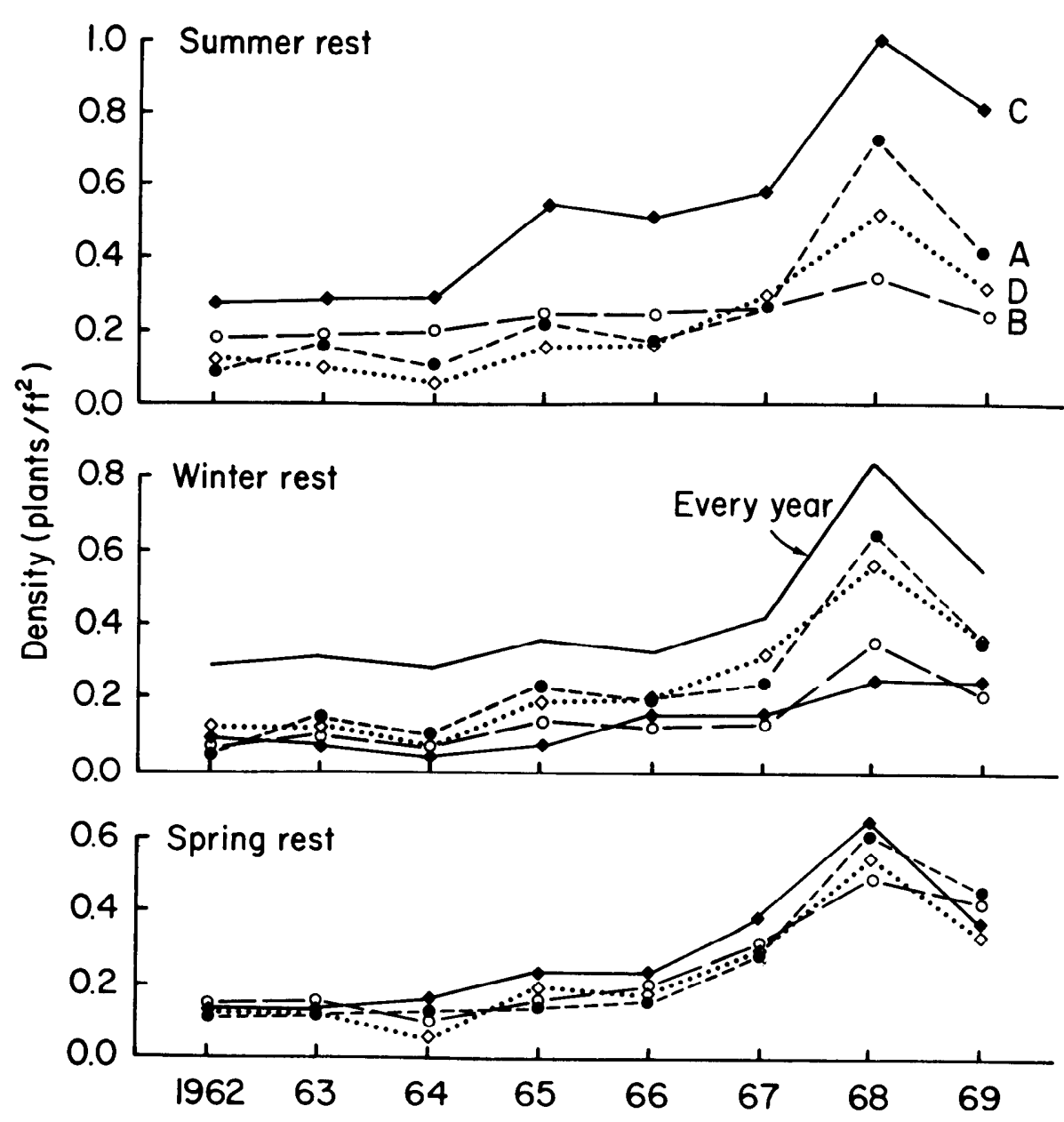

Fig. 1. Density changes for perennial grasses other than Rothrock grama under rest in summer. winter, and spring: $A, 1$ year in $3 ; B, 2$ years in $3 ; C, 3$ years in 4; and $D$, continuous yearlong 
Table 3. Density (no./ $\mathbf{f t}^{2}$ ) and herbage production (lb/acre, air dry) of perennial grasses. (Adjusted 1968-69 means from analyses of covariance; 1962-63 means used as covariant.) ${ }^{1}$

\begin{tabular}{|c|c|c|c|c|}
\hline \multirow[b]{2}{*}{ Rest period } & \multirow[b]{2}{*}{ Frequency } & \multicolumn{2}{|c|}{ Density of perennial grasses } & \multirow[b]{2}{*}{$\begin{array}{l}\text { Herbage production } \\
\text { all perennial grasses }\end{array}$} \\
\hline & & $\begin{array}{c}\text { Other than } \\
\text { Rothrock grama }\end{array}$ & All & \\
\hline Summer & $1 / 3$ & $0.60 \mathrm{bc}$ & $0.95 b$ & $72 b$ \\
\hline Winter & $1 / 3$ & $0.53 \mathrm{bc}$ & $0.85 b$ & $88 \mathrm{~b}$ \\
\hline Spring & $1 / 3$ & $0.60 \mathrm{bc}$ & $1.31 \mathrm{ab}$ & $78 \mathrm{~b}$ \\
\hline Spring-summer & $1 / 3$ & $0.78 \mathrm{bc}$ & $1.15 \mathrm{ab}$ & $101 b$ \\
\hline Yearlong & $1 / 3$ & $0.75 b c$ & $1.20 \mathrm{ab}$ & $88 b$ \\
\hline Summer & $2 / 3$ & $0.27 c$ & $0.87 \mathrm{~b}$ & $55 b$ \\
\hline Winter & $2 / 3$ & $0.40 \mathrm{c}$ & $0.61 \mathrm{~b}$ & $45 b$ \\
\hline Spring & $2 / 3$ & $0.47 \mathrm{c}$ & $0.60 \mathrm{~b}$ & $53 b$ \\
\hline Spring-summer & $2 / 3$ & $1.36 \mathrm{a}$ & $1.80 \mathrm{a}$ & $226 a$ \\
\hline Yearlong & $2 / 3$ & $1.02 \mathrm{ab}$ & $1.30 \mathrm{ab}$ & $132 b$ \\
\hline Summer & $3 / 4$ & $0.63 \mathrm{bc}$ & $1.19 \mathrm{ab}$ & $106 b$ \\
\hline Winter & $3 / 4$ & $0.38 \mathrm{c}$ & $0.66 \mathrm{~b}$ & $61 b$ \\
\hline Spring & $3 / 4$ & $0.51 \mathrm{bc}$ & $0.82 b$ & $75 b$ \\
\hline Winter & $4 / 4$ & $0.43 c$ & $0.69 b$ & $66 \mathrm{~b}$ \\
\hline None & - & $0.49 b c$ & $0.70 \mathrm{~b}$ & $64 b$ \\
\hline
\end{tabular}

${ }^{1}$ Numbers in the same column followed by different letters are significantly different at $95 \%$ level.

springs, or 3 or 4 winters, out of 4 did not help either. Summer rest 3 years out of 4 , which resulted in a more rapid density increase than did yearlong grazing, was the single exception.

The 2-year-in-3 schedule provides a ready comparison between rest periods. Spring-summer rest produced the greatest increases in perennial grass density (Fig. 2 ). Increases in density of perennial grasses under yearlong and spring-summer rest were small at first but became more pronounced as the study progressed.

Spring-summer and yearlong rest 2 years out of 3 were both superior to yearlong grazing, and gains under yearlong or spring-summer rest 1 year out of 3 likewise showed upward trends. Differences among the latter three schedules were not significant. We cannot explain why grasses responded more strongly to spring-summer than to yearlong rest on the 2-year-in-3 schedule. Perhaps winter grazing between the two spring-summer periods may increase seedling establishment by trampling seed into the soil or by removing standing herbage that might prevent establishment of seedlings that require strong light.

All species exhibited sharp year-to- year changes in density. Grass density and yield, which were low in 1962, improved on most plots during the study period. Year-to-year changes by some species were affected by rest, others were not.

\section{Santa Rita threeawn}

Santa Rita threeawn, the most abundant perennial grass, incrcased most on plots under spring-summer or yearlong rest 2 years out of 3 (Fig. 3). Summer protection 3 years out of 4 also helped. These protection schedules enabled Santa Rita threeawn to maintain increased density even under adverse conditions at the end of the study.

Yearlong and spring-summer rest 2 years out of 3 also increased herbage production of Santa Rita threeawn, even though yields were lower in 1968 and 1969 than at their high point in 1967. Final yields for ranges rested yearlong 2 years out of 3 were about twice as great as on range grazed yearlong; those rested in spring and summer 2 years out of 3 produced five times as much Santa Rita threeawn as did plots grazed yearlong.

\section{Rothrock grama}

The second most abundant perennial grass on the site was Rothrock grama. This prolific-seeding, short-lived species behaves somewhat as an annual. The density of Rothrock grama was very low in 1962, and it fluctuated greatly from year to year (Fig. 3). Rest 2 years out of

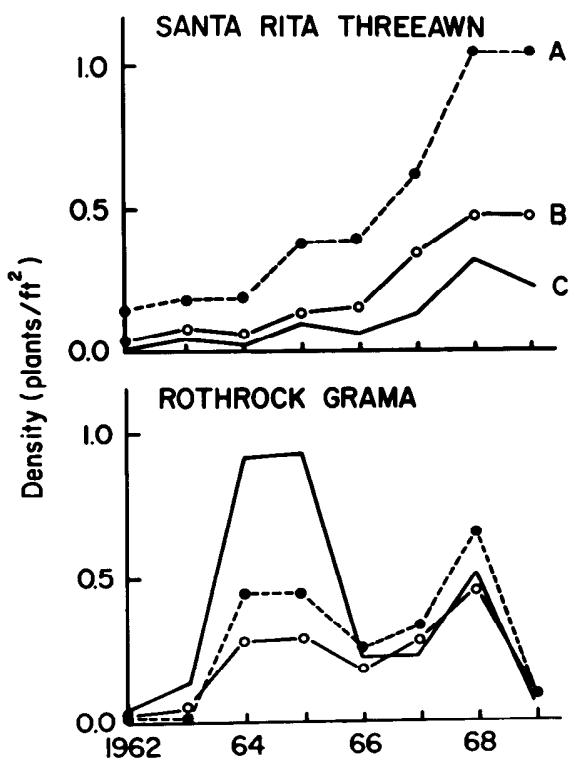

Fig. 3. Density changes for Santa Rita threeawn and Rothrock grama under $A$, rest March. October 2 years out of $3 ; B$, rest yearlong 2 years out of 3 ; and $C$, continuous yearlong grazing.
Fig. 2. Density changes for perennial grasses other than Rothrock grama on range rested 2 years out of 3 for the periods $A$, March-June; B, July-October; C, November-February; D, MarchOctober; $E$, yearlong; and $F$, continuously grazed yearlong. 


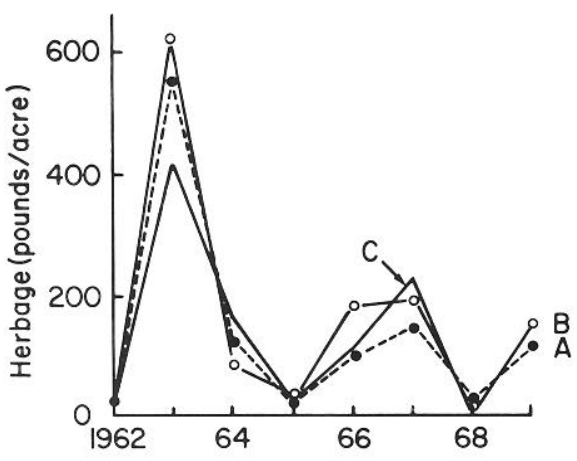

Fig. 4. Herbage production of annual grasses under $A$, rest March-October 2 years out of 3; $B$, yearlong rest 2 years out of 3; and $C$, yearlong grazing.

3 , whether for a full year or for 8 months, was of no apparent benefit. By 1969 the density and yield of Rothrock grama were down almost to the original level.

\section{Tall threeawns}

Density and yield of tall threeawns increased more under spring-summer rest 2 years out of 3 than under yearlong grazing, but differences among other schedules were negligible.

\section{Annual grasses and perennial forbs}

Yields of annual grasses fluctuated very sharply from year to year and were not affected by protection schedules (Fig. 4).

The final density of all perennial forbs was higher under spring-summer rest 2 years in 3 than under any other schedule, but the average rate of increase in density during the 8-year period did not differ significantly among treatments. The most abundant perennial forbs were Arizona evolvulus and leatherweed croton. Evolvulus, a palatable perennial forb, responded as did perennial grasses. Grazing schedules had no discernible effect on density changes in croton which, unlike evolvulus, is quite unpalatable. It seems reasonable that the palatable species responded to rest schedules but the unpalatable species did not.

\section{Utilization}

Average utilization of perennial grasses during the study period was heavy. For most species, utilization at the end of June usually exceeded $60 \%$ on plots that had been grazed since March 1. Because all plots were near water, one original concern was that cattle might graze off the accumulated herbage from rested plots very quickly after the exclosures were removed. Actually, the ungrazed herbage on plots that were opened to grazing in November after summer rest still stood out conspicuously 6 weeks later (Fig. 5), and utilization did not approach that of the surrounding range until May or June. Apparently, utilization was retarded by allowing vegetation to mature before grazing started.

Average utilization of perennial grasses at the end of June for all treatments and years was over $70 \%$ on plots that had been grazed continuously for the preceding 12 months or that had been rested in winter only. Use on plots that had been rested in summer then grazed in winter and spring averaged $61 \%$. Use on plots grazed in summer and winter and then rested in the spring was $52 \%$; use on plots grazed only in winter was $22 \%$. Apparent use as observed at the end of June was reduced most by spring rest and least by rest in winter.

Each year of the 3-year cycles that provided spring-summer rest 2 years out of 3 had a different grazing sequence for the 12-month period ending June 30 . There were three sequences: grazed during winter and spring, grazed in winter only, and grazed during summer and threeawn and Rothrock grama was highest in years when grazed both in winter and spring and lowest when grazed only in winter (Table 4). Thus utilization was cyclic, with heavy, light, and moderate levels on successive years.

Table 4. Effect of grazing schedule on utilization (\%) recorded at the end of June on Santa Rita threeawn and Rothrock grama.

\begin{tabular}{lcc}
\hline \hline & \multicolumn{2}{c}{ Utilization June 30 } \\
\cline { 2 - 3 } \multicolumn{1}{c}{ Seasons grazed } & $\begin{array}{l}\text { Santa Rita } \\
\text { threeawn }\end{array}$ & $\begin{array}{c}\text { Rothrock } \\
\text { grama }\end{array}$ \\
\hline Winter and spring & 65 & 60 \\
Winter & 15 & 13 \\
Summer and winter & 33 & 45 \\
Average & 38 & 39 \\
\hline
\end{tabular}

\section{Discussion}

Average increases in density of perennial grasses verify that there were relatively few large differences among treatments (Table 5). The range in treatment means in $1962(0.06-0.29)$ however, was less than $20 \%$ as great as in 1969 $(0.18$ - 1.32). The greatest gains were made under spring-summer rest 2 years out of 3 , and the second best under yearlong rest 2 years out of 3 (Fig. 2). Summer rest 3 years out of 4 finished high also; but plots under this treatment

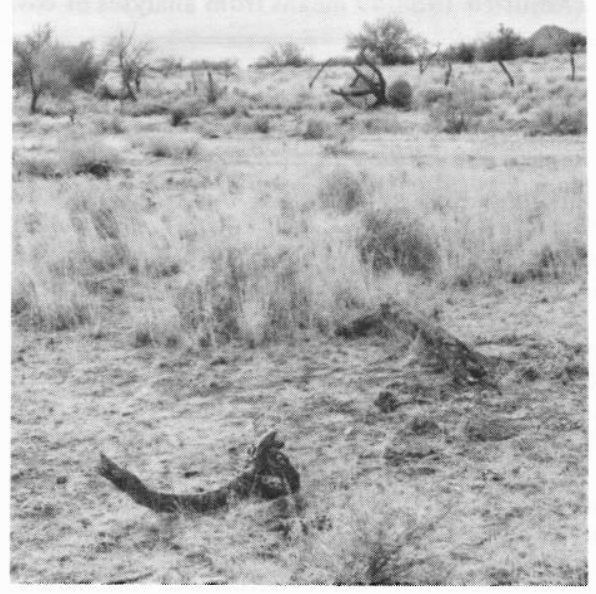

Fig. 5. Ungrazed herbage on plots rested JulyOctober usually contrasted sharply with adjacent continuously grazed range for several weeks or months after exclosure was removed. This picture was taken December 17, 1965, 6 weeks after exclosure was removed.

had the greatest initial density (0.28), while those rested yearlong 2 years out of 3 started second from the lowest (0.07). Summer rest 3 years in 4 increased grass density not quite three times, but yearlong rest 2 years in 3 increased grass density over 11 times.

The percentage of time study plots were ungrazed ranged from 0 on check plots to 67 for plots rested yearlong two years out of three. Densities of grasses other than Rothrock grama increased under all treatments. In general, singleseason treatments that rested the range from $11 \%$ to $33 \%$ of the time increased density little if any more than no rest at all $\left(r^{2}=0.01\right)$ (Fig. 6).

\section{Strengths and Limitations of Results}

These results were obtained on small

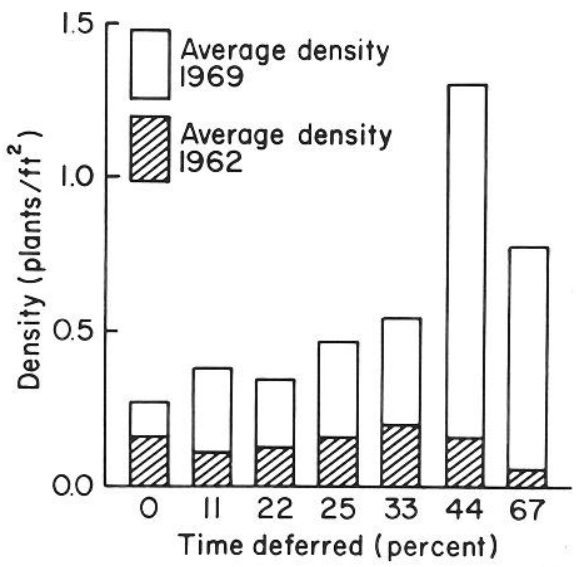

Fig. 6. Changes in density of perennial grasses other than Rothrock grama in relation to percent of time deferred. 
Table 5. Initial (1962) and final (1969) densities (no./ $\mathrm{ft}^{2}$ ) for perennial grasses other than Rothrock grama.

\begin{tabular}{|c|c|c|c|c|c|c|}
\hline \multirow{2}{*}{$\begin{array}{c}\text { Season } \\
\text { rested }\end{array}$} & \multirow{2}{*}{$\begin{array}{c}\text { Year } \\
\text { measured }\end{array}$} & \multicolumn{5}{|c|}{ Frequency of rest } \\
\hline & & 1 year in 3 & 2 years in 3 & 3 years in 4 & All years & Average \\
\hline None & $\begin{array}{c}1962 \\
1969 \\
\text { Increase }\end{array}$ & & & & & $\begin{array}{l}.12 \\
.32 \\
.20\end{array}$ \\
\hline Nov.-Feb. & $\begin{array}{c}1962 \\
1969 \\
\text { Increase }\end{array}$ & $\begin{array}{l}.10 \\
.33 \\
.23\end{array}$ & $\begin{array}{l}.06 \\
.18 \\
.12\end{array}$ & $\begin{array}{l}.09 \\
.20 \\
.11\end{array}$ & $\begin{array}{l}.29 \\
.52 \\
.23\end{array}$ & $\begin{array}{l}.14 \\
.31 \\
.17\end{array}$ \\
\hline Mar.-Jun. & $\begin{array}{c}1962 \\
1969 \\
\text { Increase }\end{array}$ & $\begin{array}{l}.10 \\
.43 \\
.33\end{array}$ & $\begin{array}{l}.13 \\
.40 \\
.27\end{array}$ & $\begin{array}{l}.11 \\
.36 \\
.25\end{array}$ & & $\begin{array}{l}.11 \\
.40 \\
.29\end{array}$ \\
\hline Jul.-Oct. & $\begin{array}{c}1962 \\
1969 \\
\text { Increase }\end{array}$ & $\begin{array}{l}.10 \\
.40 \\
.30\end{array}$ & $\begin{array}{l}.19 \\
.24 \\
.05\end{array}$ & $\begin{array}{l}.28 \\
.82 \\
.54\end{array}$ & & $\begin{array}{l}.22 \\
.49 \\
.27\end{array}$ \\
\hline Mar.-Oct. & $\begin{array}{c}1962 \\
1969 \\
\text { Increase }\end{array}$ & $\begin{array}{l}.13 \\
.59 \\
.46\end{array}$ & $\begin{array}{r}.16 \\
1.32 \\
1.16\end{array}$ & & & $\begin{array}{l}.14 \\
.96 \\
.82\end{array}$ \\
\hline Yearlong & $\begin{array}{c}1962 \\
1969 \\
\text { Increase }\end{array}$ & $\begin{array}{l}.12 \\
.60 \\
.48\end{array}$ & $\begin{array}{l}.07 \\
.79 \\
.72\end{array}$ & & & $\begin{array}{l}.10 \\
.70 \\
.60\end{array}$ \\
\hline
\end{tabular}

plots where the timing of grazing was not natural. Another limitation was that the study was conducted on range in poor condition, where the bulk of the forage was produced by increaser or invader species. For some applications this may be an advantage, however, because range in poor condition often has not improved under grazing systems that were acceptable to the rancher. Finally, the results were obtained without control of grazing intensity, and utilization during grazed periods was frequently high. This too is encouraging, because occasional heavy use is difficult to avoid.

Results of this study support the view that little benefit is gained by resting the range for only part of the normal grazing period. For example, it does not seem likely that any of the five specific systems that failed at Woodward, Okla. (Mcllvain and Shoop, 1969) would work under our semidesert conditions. Nor would 4 month's rest out of 16 as advocated by Merrill (1969) be expected to help much on the Santa Rita.

Ileady (1961) concluded that yearlong grazing at reasonable stocking rates was the best way to manage California annual range. Likewise, this study showed that none of the rest schedules improved production of annual grasses or of Rothrock grama, a short-lived perennial. Still, yearlong grazing is not recommended for semidesert range because ranges that support only Rothrock grama and annuals can only be rated as in poor condition. Heady's view that yearlong grazing amounts to partial deferment every year if grazing is proper, conflicts with those of Ellison (1960) and of Hormay and Talbot (1961), who concluded that selective grazing could not be avoided under continuous grazing. Results of this study would seem to support the latter views. Since rest less than 33\% of the time was not helpful, results in this study also would seem to support Hormay's (1970) recommendation that up to $40 \%$ or more of the range should be rested each year.

Ellison (1956) also suggested that if an engineer must use a safety factor of at least four in designing a bridge, a range manager, because his data are more variable, should use safety factors at least as large. Perhaps spring-summer rest 2 years out of 3 will provide a reasonable safety factor if forage consumption in a grazing period is limited to $50-60 \%$ of the herbage on only one-third of the range.

The importance of fitting a rest schedule to the needs of the plants is evident in past results on the Santa Rita. Rest each year May-October or November-April, for example, was more detrimental to perennial grasses than was continuous yearlong grazing (Martin, 1970). Both schedules rested the range about half the time. Rest May-October was the least desirable, probably because forage removal during the spring was twice as rapid as under yearlong grazing. In another study, range rested alternate years during the summer growing season (about 12\% of the time) improved no faster than did ranges that were grazed yearlong at comparable intensities.
Past results from the Santa Rita show that the impact of weather on short-term vegetation changes is often greater than the influence of management. Results in this study also indicate that forage stands will improve in favorable growing seasons and decline in drought under almost any grazing schedule. Thus, weather effects often override treatment effects, and an adequate test of a grazing system should include good and bad as well as average growing seasons.

\section{A Proposed Grazing System}

Can a feasible grazing system be based on the findings of this study? Springsummer rest 2 years out of 3 was the best schedule by a wide margin. The essential features of a three-pasture system based on this result might be: (1) the number of cattle will be the total that would be carried on the three pastures if all were grazed yearlong, (2) the stocking rate will be the same each year, (3) only one pasture will be grazed at a time, and (1) in the event of severe forage scarcity, cattle may be moved ahead of schedule to avoid livestock losses or damage to the range, and the rest schedule will be resumed when forage production improves. The normal schedule would provide spring-summer rest and winter rest 2 years out of 3 (Table 6).

Table 6. Scheduled "graze" and "rest" periods for a 3-year cycle in a three-pasture system that provides spring-summer and winter rest 2 years out of 3 .

\begin{tabular}{|c|c|c|c|c|}
\hline \multirow[b]{2}{*}{ Year } & \multirow[b]{2}{*}{ Season } & \multicolumn{3}{|c|}{ Pasture } \\
\hline & & 1 & 2 & 3 \\
\hline $1 \mathrm{st}$ & $\begin{array}{l}\text { Spring-summer } \\
\text { Winter }\end{array}$ & $\begin{array}{l}\text { Graze } \\
\text { Rest }\end{array}$ & $\begin{array}{l}\text { Rest } \\
\text { Rest }\end{array}$ & $\begin{array}{l}\text { Rest } \\
\text { Graze }\end{array}$ \\
\hline 2nd & $\begin{array}{l}\text { Spring-summer } \\
\text { Winter }\end{array}$ & $\begin{array}{l}\text { Rest } \\
\text { Graze }\end{array}$ & $\begin{array}{l}\text { Graze } \\
\text { Rest }\end{array}$ & $\begin{array}{l}\text { Rest } \\
\text { Rest }\end{array}$ \\
\hline $3 \mathrm{rd}$ & $\begin{array}{l}\text { Spring-summer } \\
\text { Winter }\end{array}$ & $\begin{array}{l}\text { Rest } \\
\text { Rest }\end{array}$ & $\begin{array}{l}\text { Rest } \\
\text { Graze }\end{array}$ & $\begin{array}{l}\text { Graze } \\
\text { Rest }\end{array}$ \\
\hline
\end{tabular}

The system provides a full year of rest before each spring-summer grazing period. Winter grazing is scheduled between the two consecutive spring-summer rest periods. This system is now being tested in three three-pasture sets on the Santa Rita Experimental Range. Until the results of this study are available, we can only anticipate how the system will affect the range, the livestock, and the rancher.

Taking the range first, I think the system will improve patterns of use and increase the vigor and reproduction of valuable forage plants. Forage improve- 
ment should be especially great on areas where cattle concentrate, as near water. Concentrated winter grazing after springsummer rest may aid grass reproduction by planting seed by trampling, as Hormay (1970) suggests, or by removing old growth that might interfere with seedling establishment. Spring-summer rest following concentrated winter grazing should give seedlings of forage plants a chance to become firmly established before they are grazed. Spring-summer grazing 1 year in 3 , even if heavy, is not expected to be seriously harmful because occasional heavy utilization did not prevent improvement of grass stands on study plots.

If the system produces dense, vigorous stands of perennial grasses that fully occupy the site, forage production will be increased and the establishment of such undesirable shrubs as mesquite and burroweed will be reduced. Reseeding, shrub control, or other range improvements can be timed to take advantage of the rest schedule. Increased herbage production together with scheduled rest periods should provide opportunities for more effective use of prescribed burning for vegetation' control.

Total stocking will be the same as if each unit were properly grazed yearlong and will be the average number of cattle required to consume $40 \%$ of the perennial grass herbage production during the past 10 years. Thus, the rate of forage consumption will be approximately tripled during grazed periods. Utilization usually will not be excessive, however, because the scheduled grazing period on each forage crop will be only $1 / 3$ as long as under yearlong grazing. Under springsummer grazing, for example, cattle will feed mainly on last year's ungrazed carryover from March until summer growth begins in July, and on current summer growth for the remainder of the period. Forage consumption July-October, although about three times as fast as under yearlong grazing, should not be much greater than yearlong grazing with one-third as many cattle.

In my opinion, this schedule will benefit livestock. The quality of forage available March-June will depend on the amount of spring growth, but usually will be low. Old herbage is better than no herbage, however, and it can be supplemented as needed to overcome specific nutritional deficiencies. Relatively heavy grazing March-June will remove much of the accumulated dead herbage. Summergrown grass, therefore, will be relatively free of dead material. It should be rela- tively palatable and nutritious, and cattle should make acceptable gains. Higher stocking rates in summer will increase the percentage of plants that are grazed each day, thereby keeping more plants in a vegetative state, and more nutritious, for a longer period.

Current forage production should be ample for the animals during most summer growing seasons. This assumption is based on the fact that $90 \%$ of the perennial grass forage is produced during the summer growth period, which averages about 9 weeks (Culley, 1943). Even at the higher stocking rates of this system, forage growth during the average summer will be greater than the rate of consumption. Thus the anticipated advantages for cattle are (1) ample carryover herbage during the March-June period when forage is most often scarce, and (2) improved forage quality during the summer growing season and early fallthe only time when cattle consistently make rapid gains.

For the rancher, one advantage is that all the cattle will be in one pasture instead of three. Fewer waters and fences will have to be watched, and less travel by truck or horse will be needed to care for the animals. Even if March 1 is too early for branding, the effort required to move the herd from the winter unit to the spring-summer unit will be more than offset by reducing the number of pastures to be rounded up by two-thirds. The fall move would be made at normal roundup time.

\section{Summary and Conclusions}

Fifteen schedules of rest and grazing, which ranged from continuous yearlong grazing to yearlong rest 2 years out of 3 , were evaluated on semidesert range from 1962 to 1969. Three 4-month rest periods: spring (March-June), summer (JulyOctober), and winter (NovemberFebruary) were defined. Protection in each season was applied (a) 1 year in 3 , (b) 2 years in 3, and (c) 3 years in 4, to plots $20 \mathrm{ft}$ square. Longer protection periods, spring-summer (March-October) and yearlong, were applied 1 year in 3, and 2 years in 3 . In addition, one set of plots was protected every winter and two sets, the controls, were grazed continuously.

Of the 15 schedules tested, spring. summer rest 2 years out of 3 produced the greatest improvement in perennial grasses.

The density and herbage yield of Santa Rita threeawn and perennial grasses other than Rothrock grama generally increased from 1962 to 1969 on both restèd and grazed plots.

Density and yield of Rothrock grama and yields of annual grasses fluctuated greatly from year to year and were not affected by rest schedules.

Winter rest did not increase density or yield of perennial grasses other than Rothrock grama no matter how frequently applied.

Spring rest did not increase yields or density of perennial grasses other than Rothrock grama when applied 1 or 2 years in 3 , or 3 years in 4 .

Summer rest 1 or 2 years in 3 did not consistently increase density or yield of perennial grasses other than Rothrock grama, but summer rest 3 years out of 4 was beneficial.

Yearlong rest either 1 or 2 years out of 3 improved the density of Santa Rita threeawn, and yearlong rest 2 years out of 3 produced the second greatest density gains for grasses other than Rothrock grama.

A three-pasture grazing system based on the findings of this study (Table 6) is being pilot tested on the Santa Rita Experimental Range. It is anticipated that this system will benefit not only the range but the livestock and the rancher as well.

\section{Literature Cited}

Culley, Matt J. 1943. Grass grows in summer or not at all. Amer. Hereford J. 34(9): 8,10.

Ellison, Lincoln. 1956. Grazing standards in range management. New Zealand Grassl. Assoc. Proc. Eighteenth Con. Canterbury Agr. Col. Lincoln, Nov. 27 to 29, 1956.

Ellison, Lincoln. 1960. Influence of grazing on plant succession of rangelands. Bot. Rev. 26(1):1-77.

Heady, Harold F. 1961. Continuous vs. specialized grazing systems: A review and application to the California annual type. J. Range Manage. 14:182-193.

Hormay, A. L. 1970. Principles of rest-rotation grazing and multiple-use land management. U.S. Dep. Agr., Forest Serv. Training Text 4 (2200), $26 \mathrm{p}$.

Hormay, A. L., and M. W. Talbot. 1961. Rest-rotation grazing...A new management system for perennial bunchgrass ranges. U.S. Dep. Agr. Prod. Res. Rep. 51, 43 p.

McIlvain, E. H., and M. C. Shoop. 1969. Grazing systems in the southern Great Plains. Abst. 22nd Ann. Meeting, Amer. Soc. of Range Manage., Calgary, Alberta, Canada, Feb. 10-13, 1969. p. 21-22.

Martin, S. Clark. 1970. Vegetation changes on semi-desert range during 10 years of summer, winter, and yearlong grazing by cattle. XI Int. Grassl. Congr. Proc. 11:23-26.

Merrill, Leo B. 1969. Grazing systems in the Edwards Plateau of Texas. Abst. 22nd Annu. Meeting, Amer. Soc. of Range Manage., Calgary, Alberta, Canada, Feb. 10-13, 1969. p. 22-23. 